\title{
MHD 緩和現象に伴うイオン異常加熱について
}

\author{
吉 田善 章 \\ (東京大学工学部)
}

（1990年 4 月18日受理 $/ 1990$ 年 6 月 8 日改訂原稿受理）

\begin{abstract}
Anomalous Ion Heating Correlated with MHD Relaxation
\end{abstract}
Zensho Yoshida

(Received April 18, 1990/Revised Manuscript Received June 8, 1990)

\begin{abstract}
An excess of magnetic energy is spontaneously released through MHD relaxation process. The released energy is dissipated by the ions and electrons. Using the classical resistivity and viscosity coefficients, the partition relation of the dissipated power into the electrons and ions has been estimated. In a driven reconnection, where the growth rate of the instability is quite large, a slight compressibility of the velocity field results in strong viscous heating of the ions. Concerning the total energy balance, there exists an anomalous resistive dissipation through mean-field current, when the resistivity distribution is not uniform. This is a counter process to the direct heating of the ions, which implies a direct loss channel for the applied energy through the electrons.
\end{abstract}

Keywords : anomalous ion heating, viscosity, MHD relaxation, helicity,

1.はじめに

MHD 緩和現象は，プラズマに与えられた余剩の磁気エネルギー（主としてトロイダル電流に起因する電磁応 力による）の自発的な開放過程である1）、誘導電場等によって駆動された系においては，平均平衡配位（mean field）の周りに摇動（fluctuation）が存在して，駆動電場と摇動電場との競合によって構造が保持されると 考えられる，摇動が，大きな振幅を持つコヒーレントなモードへと発達する場合，この緩和過程は間欠的現象 の印象を与えるが，多数モードの非線型結合によってランダムな位相の摇動が形成される場合は，連続的な緩 和が起こると言ってよい. sawtooth 振動に伴う電流分布の再編成は前者の代表的な実例である，又，RFPで 観られる乱流的なダイナモ効果による逆磁場の保持は後者の好例と言えよう．

さて，この様な MHD 緩和過程において，開放された磁気エネルギーはいったいどうなるのであろうか？

Department of Nuclear Engineering, The University of Tokyo, Hongo, Tokyo 113. 
熱力学的に考えると, 構造の保持は一定の摇らぎに伴うエントロピーの生産と表裏を共にしている筈である. 駆動電場によって, 先ず磁気エネルギーとしてプラズマに与えられたエネルギーの「余唾分」は, 緩和過程を 通じて熱化しつつ, mean field の構造を保持するのである. エネルギーの流れは, 入力エネルギーとバラン スするだけのエネルギーが, 最終的には系外へ熱として放出されると言うパスを成すわけであるが, その過程 において, 電子のチャンネルとイオンのチャンネルとがどの様に使い分けられながら緩和が進行するのかが, プラズマ物理としては興味深い問題となる，所謂「異常加熱」は，緩和によって開放された磁気エネルギー が，プラズマ中のイオンや電子の熱エネルギーへ，一旦有意なレベルだけ投入されることを言う．

勿論, 緩和過程に伴う摇動によって, プラズマ中の輸送現象も大きく変化する，緩和による異常加熱を定量 的に把握できるのは, 磁気的な自由エネルギーが大きな系に限られるであろう. 即ち, 緩和過程によって熱化 されるパワーが, 通常の加熱（オーミック加熱や追加熱）によるパワーと比べて同程度以上の場合に，この問 題が重要になるのであって, 逆にそれが小さい場合は, 所謂「異常輸送」（通常加熱エネルギーに対する）の みが支配的な現象になるであろう。具体的には，前者のカテゴリーに入るものとしてRFP, ULQ やスフェロ マック等のピンチプラズマ系や，太陽フレアなどの宇宙プラズマ系が考えられる．

MHD 緩和に伴う異常加熱の問題が近年クローズアップされている背景には, RFP やULQの実験で, イオン 温度の異常を示すデータが得られ始めていることがある（第 2 節参照） ${ }^{2-6)}$. 勿論, 核融合研究の立場から は，イオンが異常に加熱されると言うことは甚だ好都合な話だと言う趣旨もある訳であるが, 物理学的にも, プラズマの挙動の基礎を理解する上で興味深いデータと言えよう。即ち, MHD 緩和で開放された磁気エネルギ 一は，イオンの直接加熱に寄与するであろうと言う予測が立ち得るのである．既にいくつかの理論モデルも登 場している ${ }^{7,8)}$. 本論文では, MHD 緩和現象について今日まで得られてきた成果を注意深く再検討しつつ, 緩 和と異常加熱との関係について基礎的な概念を整理したい.

\section{2. 背景と予備的な考察}

\section{2-1 MHD 緩和とイオンの直接加熱}

RFP の実験では，各装置に於て1985年頃からイオン温度の測定が精力的に行われ，イオンの異常加熱機構の 存在を示唆するデータが出始めた ${ }^{2-5)}$. RFP プラズマは純粋に誘導電場のみによって加熱されているが, イオ ン温度は電子温度を上回るレベルに達し, 又イオンの加熱率も電子ーイオンのエネルギー緩和率を上回ること が示された，従って，イオンを直接加熱する機構が存在すると考えられる.

この様なイオンの直接加熱には MHD 緩和現象に伴う異常加熱か関与していると考えられている.MHD 緩和 においては，不安定性（主として電流駆動モード）によって励起されたプラズマの運動が作る摇動電場（v× B）が本質的な役割を果たす．プラズマの流体的な運動量は主としてイオンの集団的運動が担っているが，こ れはイオンの粘性によって熱化され得る。即ち, プラズマの余剩磁気エネルギーは電流駆動モードによって一 旦流体的運動エネルギー（イオンの集団的運動エネルギー）に変換され，更に粘性によってイオンの熱エネル 
ギーへと変換されて行く，と言うシナリオが考えられる7).この考え方には大筋において首肯させられるので あるが，定量的な検討を行うに際して幾つかの問題が出て来る．以下，それらを整理しょう。

\section{2-2 摇動の粘性散逸と抵抗散逸}

先ず, 摇動電流を介しての電気抵抗散逸が, 摇動の全散逸の中でどれだけの寄与を持つのかと言う問題を考 える必要がある。即ち, 不安定性が作る摇動電場によって, 一旦電流のエネルギー（摇動場の磁気エネルギ 一) に変換され，更に抵抗によって電子の熱エネルギーへと変換されて行くと言うチャンネルが存在する訳 で,この電子のチャンネルと, 先に述べたイオンのチャンネルとの間で散逸エネルギーの分配はどの様になる のかと言う問題を考えねばならない.

ところが,これまでの MHD 緩和モデルではイオンのチャンネルは殆ど考慮されておらず，その意味で通常 の緩和モデルでは電子のチャンネルだけでエネルギー散逸を説明してきた事になる，例えば，乱流ダイナモモ デルでは不安定性の非線型発展が波数空間でモードのカスケードを生じ, 抵抗散逸（〜 $\quad \eta \mathrm{k}^{2}, \mathrm{k}$ : 波数 $)$ が促進される効果を重視する ${ }^{9,10)}$. J.B. Taylorの緩和モデルでは,こうしたエネルギー散逸がヘリシティ 一の散逸よりも急速に起こることによってRFP の形成を説明している ${ }^{11)}$. 又, 種々の MHD シミュレーショ ンでは, 粘性項を無視した（数值安定化の為の人為項のみ）方程式系が用いられてきた，磁気再結合が起こる 近傍に集中した摇動電流がシミュレートされており，その抵抗散逸が前述のカスケードに対応すると解釈され ている12-14).

勿論, これらの MHD 緩和の研究では, 形成される構造の方が主題であって, たとえ散逸されるエネルギー の方に充分な注意が払われてなくとも，その結論の大筋には影響がないのかも知れない.しかし，MHD 緩和と イオン異常加熱とを統一的に理解するためには，この問題を調べなくてはならない. 第 3 節では散逸エネルギ 一のイオン及び電子への分配率を計算し，実はイオンチャンネルの散逸が支配的であることを示そう。

\section{2-3 平均場による異常散逸}

次の問題は平均場 (mean field) に よる抵抗散逸の評価である。誘導に よって系に入力される全エネルギーの 散逸は, 平均場の電流による抵抗散逸 と，摇動による散逸（イオンの粘性散 逸と電子の抵抗散逸）に分配される (図 1 参照)。ここで, 平均場による異 常散逸（anomalous dissipation）が存 在し得ることに注意したい15)。この

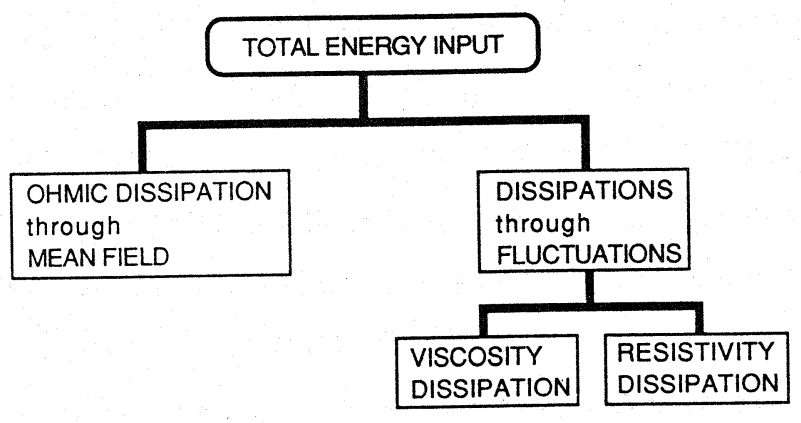

図1.オーミックドライブされたプラズマに於ける エネルギー散逸チャンネル. 
研究論文

異常散逸は, 局所的な電子チャンネルの強いエネルギー損失と, 電流密度分布の形成機構の”異常”とによっ て引き起こされる。”正常”な場合には，電気抵抗が大きな低温のプラズマ領域には少ない電流しか流れず， ジュール散逸は小さくなる，従って，オーミック入力は，閉じ込めが良好な高温・低抵抗の領域に集中し，総 体として良好な閉じ込娃性を得ることができる。しかし, 仮に強いエネルギー損失を持ち高温になり得ない 領域（例えば磁気面が乱れたエッジ近傍）に高い電流密度が与えられると，ジュールエネルギー散逸はこの低 温領域に集中し，結果エネルギーはこの電子チャンネルを通じて激しく失われることになる.

この様な状況はプラズマヤの電場が著しく不均一な場合でないと生じないが，MHD 緩和現象の下ではこうし た状況が起こり得る。緩和過程によって自己発生する電場（所謂ダイナモ電場）によって，プラズマ中の電流 分布が自己調整されるからである，放電プラズマではしばしば磁気エネルギーがプラズマの運動を支配するだ けの大きな自由エネルギーを持ち, 従って磁場配位（従って電流密度分布）は，プラズマが安定化する構造へ と自己形成を起こす傾向を持つ。この場合，電流密度分布と抵抗率分布との相関は小さくなり，高抵抗領域に 電流を流すのに必要な電場はプラズマの自己場によって与えられると考えられる，第 4 節で示すように，プラ ズマが自己形成する配位におけるジュール散逸は，古典的に電流が拡散した系（正常な電流分布の系）での ジュール散逸よりも常に大きい.

実験的に摇動成分の散逸パワーを算出する際は，全入力から平均場による散逸分を差し引くことになるが, 平均場成分の評価には注意を要するのである，平均場による異常散逸分は，電子チャンネルによるエネルギー 損失を反映したものであるから，摇動成分がイオン加熱に寄与することと比べると全く対照的である.

\section{3. 粘性によるイオン異常加熱}

\section{3-1 粘性散逸と抵抗散逸}

MHD 摇動を介して散逸されるエネルギーが，イオンと電子とにどの様に分配されるかを計算しょう，イオン の熱エネルギーへの変換は, プラズマの流速の摇動 $\mathbf{v}_{1}$ がイオンの粘性によって散逸されることで起こり, 一 方電子の熱エネルギーへの変換は摇動電流 $\mathbf{j}_{1}$ が抵抗によって散逸されることで起こる. 即ち, イオン及び電 子に入る加熱パワー $P^{\mathrm{i}}$ と $P^{\mathrm{e}}$ は各々

$$
\begin{aligned}
& P^{\mathrm{i}}=\int \mathbf{v}_{1} \cdot \operatorname{div} \Pi \mathrm{d} v, \\
& P^{\mathrm{e}}=\int \mathbf{B}_{1} \cdot \operatorname{rot}\left(\eta \mathbf{j}_{1}\right) \mathrm{d} v / \mu_{0}
\end{aligned}
$$

で与えられる. 但し, $\Pi$ は応力テンソル, $\operatorname{rot} \mathbf{B}_{1}=\mu_{0} \mathbf{j}_{1}, \eta$ は抵抗率を表す. 部分積分を行い, 表面項 を無視する（積分を摇動全体に互ってとる）と，

$$
\begin{aligned}
& P^{\mathrm{i}}=\int\left[\nu_{\mathrm{d}} \Omega_{\mathrm{d}}^{2}+\nu_{\mathrm{r}} \Omega_{\mathrm{r}}^{2}\right] \mathrm{d} v, \\
& P^{\mathrm{e}}=\int \eta j_{1}^{2} \mathrm{~d} v
\end{aligned}
$$


と書くことができる。但し, $\Omega_{\mathrm{d}}^{2}=\left(\operatorname{div} \mathbf{v}_{1}\right)^{2}, \Omega_{\mathrm{r}}^{2}=\left(\operatorname{rot} \mathbf{v}_{1}\right)^{2}$ である.

$P^{\mathrm{i}}$ の第 1 項及び第 2 項を各々 $P_{\mathrm{d}}^{\mathrm{i}}, P_{\mathrm{r}}^{\mathrm{i}}$ と書くことにする.

古典的な粘性係数, 抵抗率は

$$
\begin{aligned}
& \nu_{\mathrm{r}}=0.3 n_{\mathrm{i}} T_{\mathrm{i}} /\left(\omega_{\mathrm{i}}^{2} \tau_{\mathrm{i}}\right), \\
& \nu_{\mathrm{d}}=\left[1+\left(\omega_{\mathrm{i}} \tau_{\mathrm{i}}\right)^{2}\right] \nu_{\mathrm{r}}, \\
& \eta=m_{\mathrm{e}} /\left(2 n_{\mathrm{e}} e^{2} \tau_{\mathrm{e}}\right)
\end{aligned}
$$

と与えられる ${ }^{16)}$ ．但し， $n_{\mathrm{i}}$ はイオン密度， $T_{\mathrm{i}}$ はイオン温度， $\tau_{\mathrm{i}}, \tau_{\mathrm{e}}$ は各々イオンーイオン, 電子ーイ オンの衝突時間, $m_{\mathrm{e}}$ は電子の質量, $\mathrm{e}$ は素電荷, $\omega_{\mathrm{i}}$ はイオンのジャイロ周波数を表す，この表式では, 高 温或は低密度の極限で ${ }_{\mathrm{d}}$ が無限に大きくなる傾向を示すが, 実際はイオンの平均自由行程 $\lambda_{\mathrm{m}}$ が采の結合長 Lより長くなると, Knudsen 数（ $\mathrm{Kn}=\lambda_{\mathrm{m}} / \mathrm{L} ）$ の 2 乗程度の補正を施す必要がある（後述）.

\section{3-2 MHD 摇動に伴う渦と電流の評価}

さて, $P^{\mathrm{i}}$ と $P^{\mathrm{e}}$ は各々摇動 $\mathbf{v}_{1}, \mathbf{j}_{1}$ に関 係した量であるから，両者を比べるために は $\mathbf{v}_{1}$ と $\mathbf{j}_{1}$ の self-consistent な関係を得 る必要がある。ここではスラブプラズマに 於ける電流駆動不安定性についての計算か らオーダー評価を導こう。

MHD 緩和現集は主として電流駆動の不

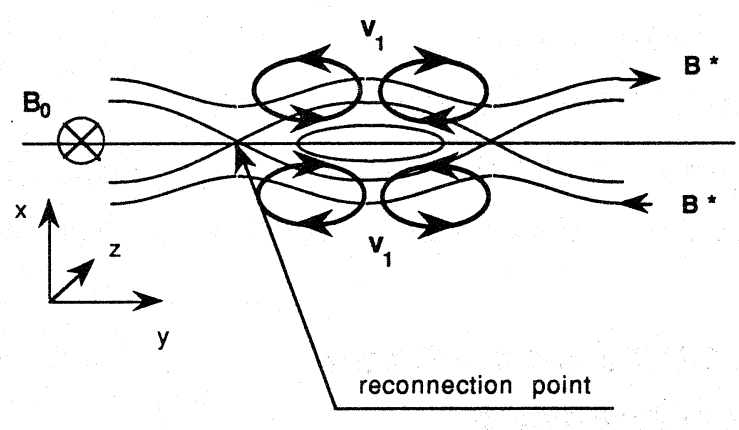

図2.磁気再結合過程のスラブモデル. 安定性によって引き起こされる磁気再結合 がその主要な基礎過程となる，摇動に伴う散逸は，この磁気再結合点近傍に局在する，図 2 は電流駆動モード による磁気再結合の様子を示す，再結合が起こる共鳴磁場を $\mathbf{B}_{0}$ と書き， $\mathbf{B}_{0}$ の方向に $z$ 軸を取る. 磁場 $\mathbf{B}$ のシ ヤー成分を $\mathrm{B} *$ とし,

$$
\mathbf{B}=B_{0} \operatorname{grad} z+\mathrm{B}^{*} \operatorname{grad} y
$$

となる局所座標を取る． $x=0$ で $\mathrm{B}^{*}=0, x$ 軸方向に磁気再結合の駆動流が流れ込んでくる．以下の基礎方 程式を用いる。運動方程式は

$$
\rho \gamma \mathbf{v}_{1}=-j_{1, z} \mathrm{~B}^{*} \operatorname{grad} x-\operatorname{grad} P,
$$


但し， $\rho$ はプラズマの質量密度， $\gamma$ は不安定性の成長率， $j_{1, z}$ は摇動電流の $z$ 成分, $P=\mathrm{p}+\mathrm{B}_{1, z} \mathrm{~B}_{0} / \mu_{0}, \mathrm{p}$ は圧力を表す。誘導法則（Faraday）の $z$ 成分を使う;

$$
\gamma B_{1, z}=\operatorname{rot}\left(\mathbf{v}_{1} \times \mathbf{B}_{0}\right) \cdot \operatorname{grad} z
$$

但し, $B_{1, z}$ は摇動磁場の $z$ 成分である。ここで, $z$ 成分については電気抵抗が無視できる。( 4 ）を書き直 すと,

$$
\gamma p_{1}^{\mathrm{m}}=-p^{\mathrm{m}}{ }_{0} \operatorname{div} \mathbf{v}_{1}
$$

但し, $p^{\mathrm{m}}{ }_{1}=B_{1, z} B_{0} / \mu_{0}, p^{\mathrm{m}}{ }_{0}=B_{0}{ }^{2} / \mu_{0}$ である．

運動方程式（3）の両辺の rot を取ると

$$
\Omega_{\mathrm{r}}=\left|\operatorname{rot} \mathbf{v}_{1}\right|=(\rho \gamma)^{-1} k_{y} j_{1, z} B^{*}
$$

但し， $k_{y}$ は $y$ 方向の波数である。， 又, 3 ）の $y$ 成分は

$$
\rho \gamma v_{1, y}=i k_{y}\left(p_{1}+p^{\mathrm{m}}{ }_{1}\right)
$$

但し， $p_{1}$ は圧力の摇動分である。低 $\beta$ の場合， $p_{1}$ は $p^{\mathrm{m}}{ }_{1}$ に対して無視できる。（ ${ }^{\prime} ）$ を用いると，

$$
\begin{aligned}
\Omega_{\mathrm{d}}=\left|\operatorname{div} \mathbf{v}_{1}\right| & =\left(\gamma / \omega_{\mathrm{A}}\right)^{2} k_{\mathrm{y}} v_{1, y} \\
& =\left(\gamma / \omega_{\mathrm{A}}\right)^{2}\left(\varepsilon k_{y}\right)^{-1} \Omega_{\mathrm{r}}
\end{aligned}
$$

を得る。但し, $\omega_{\mathrm{A}}=\left(p_{0}^{\mathrm{m}} / \rho\right)^{1 / 2} k_{\mathrm{y}}$ は Alfvén 周波数, $\varepsilon$ は渦の $x$ 方向の厚みを表す.

以上の $\Omega_{\mathrm{r}}, \Omega_{\mathrm{d}}$ の表式を式（1）に用い，式（2）を使うと，

$$
\begin{aligned}
& P_{\mathrm{r}}^{\mathrm{i}} / P^{\mathrm{e}}=0.3\left(m_{\mathrm{i}} / m_{\mathrm{e}}\right)^{1 / 2} \beta_{\mathrm{i}}\left(\omega_{\mathrm{A}} / \gamma\right)^{2}(\lambda \varepsilon)^{2}, \\
& P_{\mathrm{d}}^{\mathrm{i}} / P^{\mathrm{e}}=0.3\left[1+\left(\omega_{\mathrm{i}} \tau_{\mathrm{i}}\right)^{2}\right] \quad\left(m_{\mathrm{i}} / m_{\mathrm{e}}\right)^{1 / 2} \beta_{\mathrm{i}}\left(\gamma / \omega_{\mathrm{A}}\right)^{2}\left(\lambda / k_{y}\right)^{2},
\end{aligned}
$$


を得る。但し, $\beta_{\mathrm{i}}=2 n_{\mathrm{i}} T_{\mathrm{i}} \mu_{0} / B_{0}{ }^{2}$ はイオンのベータであり, 以下の関係を用いた

$\mathrm{B}^{*} \sim \varepsilon \mathrm{d} \mathrm{B}^{*} / \mathrm{dx} \sim \varepsilon \lambda \mathrm{B}_{0}$

但し, $\lambda=\mu_{0} \mathrm{j} / / / B_{0}, j_{/ /}$は磁場に平行な平均場の電流密度である. RFPでは $\lambda \sim 2 \theta / \mathrm{a}, \theta$ はピンチ 比, $\mathrm{a}$ は小半径である.

代表的な数值をあたってみよう. RFP 等の典型的な值, $T_{\mathrm{i}}=T_{\mathrm{e}}=100 \mathrm{eV}, n_{\mathrm{e}}=n_{\mathrm{i}}=10^{20} \mathrm{~m}^{-3}, B_{0}=0.3$ $\mathrm{T}$ の場合を考える、駆動型の磁気再結合では，( $\left.\omega_{\mathrm{A}} / \gamma\right)$ は10程度である。これらの数值を用いると，

$$
\begin{aligned}
& P_{\mathrm{r}}^{\mathrm{i}} / P^{\mathrm{e}} \sim 10^{-2} \\
& P^{\mathrm{i}} / P^{\mathrm{e}} \sim 10^{2}
\end{aligned}
$$

といった評価を得る。但し，再結合層（resistive layer）の厚みを $10^{-2} \mathrm{a}$ 程度と評価した。この結果，ほと んどの散逸は $P_{\mathrm{d}}^{\mathrm{i}}$ で与えられることが分かる。但し，これより高温，或は低密度の領域では平均自由行程が 長くなり, 古典的な ${ }_{\mathrm{d}}$ は使えなくなり, $P^{\mathrm{i}}{ }_{\mathrm{d}}$ は相対的に小さくなる, 又, 通常の tearing mode の様に成長 率 $\gamma$ が小さい場合も, $P_{\mathrm{d}}^{\mathrm{i}}$ は小さくなり, むしろ $P_{\mathrm{r}}^{\mathrm{i}}$ が支配的になる.

\section{4. 平均場による異常散逸とエネルギー損失}

前節の計算は摇動 $\mathbf{j}_{1}, \mathbf{v}_{1}$ に関する散逸の評価であったが，本節では平均場による散逸を計算し，MHD 緩 和現象が支配する平衡配位では，平均場による散逸に anomaly が生じることを示そう，先ず，ヘリシティー とエネルギーのバランスの関係を整理しておく。

\section{4-1 ヘリシティーバランスとエネルギーバランス}

流体力学的な方程式系に対する所謂 a priori 評価の手法は, いろいろな積分物理量の時間変化に対する基

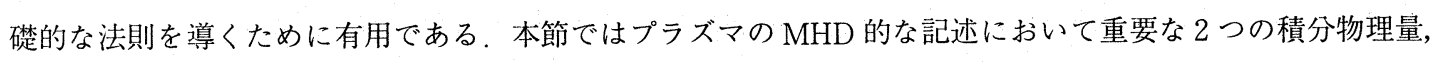
磁気ヘリシティーとエネルギーに関する a priori 評価を復習し，プラズマ理論に応用する上での両者の違い について考察する.

プラズマ中の磁束密度 $\mathrm{B}$ の分布はオームの法則

$$
\partial \mathbf{B} / \partial_{\mathrm{t}}=-\operatorname{rot}\left(\eta / \mu_{0}\right) \operatorname{rot} \mathbf{B}+\operatorname{rot}(\mathbf{v} \times \mathbf{B}), \quad \operatorname{div} \mathbf{B}=0
$$

によって支配される，速度場 $\mathbf{v}$ はプラズマの流体的運動方程式によって支配されているとする，もし完全導 
体壁の境界条件を課すならば, 境界上で電場 $\mathrm{E}$ の接線成分が 0 となり, プラズマへの磁気エネルギー流速

(Poynting vector) は 0 となる。ここではこの様な境界条件を考えないで，プラズマは外界と磁気エネルギ 一を介しても結合しているとする。

式（5）の線型散逸項 $-\operatorname{rot}\left(\eta / \mu_{0}\right) \operatorname{rot} \mathrm{B}$ は抵抗による磁気エネルギーの散逸を表す。対流型非線型項 $\operatorname{rot}(\mathbf{v} \times \mathbf{B})$ は, プラズマの流れによって磁気エネルギーが空間的に輸送されること, 及び磁気エネルギーと運 動エネルギーとの相互交換を表す．

先ず磁気ヘリシティーの時間变化を計算しょう，磁気へリシティーは放電プラズマ中の電流分布，特に磁場

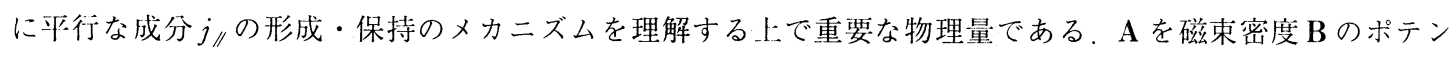
シャル, 即ち $\mathbf{B}=\operatorname{rot} \mathbf{A}$ とする， $\mathbf{A}$ を決定するためには適当なゲージ条件と境界条件が卢えられねばなら ない. 領域 $\Omega$ 内の磁気ヘリシティー $\mathrm{K}$ は

$$
K=\int \mathbf{A} \cdot \mathbf{B} \mathrm{d} v
$$

と定義される，Kの時間変化を計算するとヘリシティーバランスの関係が導かれる，即ち，

$$
\mathrm{d} K / \mathrm{d} t=-\int \operatorname{div} \mathbf{F}_{\mathrm{h}} \mathrm{d} v-\int \eta \mathbf{j} \cdot \mathbf{B} \mathrm{d} v
$$

但し, $\eta \mathbf{j} \cdot \mathbf{B}(\eta$ : 抵抗率, $\mathbf{j}$ : 電流密度 $)$ はヘリシティー散逸を表し, ヘリシティー束は $\mathbf{F}_{\mathrm{h}}=-\partial_{\mathrm{t}} \mathrm{A}$ $\times \mathbf{A}+2 \phi \mathbf{B} \quad(\phi:$ スカラーポテンシャル) と表される. 完全導体壁で囲まれた $\eta=0$ のプラズマでは $\mathrm{d} K / \mathrm{d} t=0$ ， 即ちへリシティーの保存が成り立つ，実際のプラズマでは有限な抵抗のためにヘリシティー の散冕が起こり，これを補うだけのへリシティー注入がなくては，その平衡状態は保持できない. ヘリシティ 一散逸は $\eta \mathbf{j} ・ \mathbf{B}$ で与えられるので, ヘリシティ一散逸は $\mathrm{j} / /$ 減衰を意味している.

保持された平衡に関するへリシティーバランスの関係は

$$
\int_{\Omega} \eta \mathbf{j} \cdot \mathbf{B} \mathrm{d} v=-\int_{\Gamma} \mathbf{n} \cdot \mathbf{F}_{\mathrm{h}} \mathrm{d} s
$$

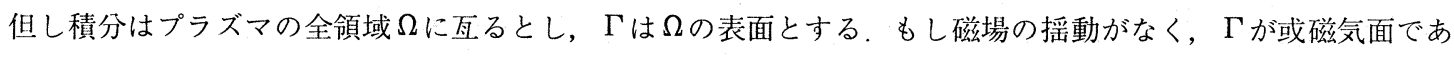
るとすると，右辺の表面積分は $V_{\mathrm{L}} \Phi_{\mathrm{t}}\left(V_{\mathrm{L}}\right.$ は周回電圧， $\Phi_{\mathrm{t}}$ はトロイダル磁束）となり，

$$
\int_{\Omega} \eta \mathbf{j} \cdot \mathbf{B} \mathrm{d} x=V_{\mathrm{L}} \Phi_{\mathrm{t}}
$$

を得る、ヘリシティーの評価式はオームの法則（5）のみから導かれ，プラズマの流体的運動や熱運動と関係 
しないために，極めてシンプルな関係式が得られる.

次にエネルギーの評価式を導こう。こちらの方はオームの法則とプラズマの運動方程式が $\mathbf{B} ・ \operatorname{rot}(\mathbf{v} \times \mathbf{B})$ を通じてカップリングするのでヘリシティー評価のように単純には行かない. 流体的なプラズマのエネルギー Wは

$$
W=\int\left[B^{2} /\left(2 \mu_{0}\right)+\rho v^{2} / 2+p /\left(\gamma_{\mathrm{s}}-1\right)\right] \mathrm{d} v
$$

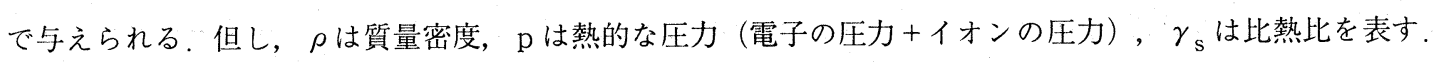
準定常状態では入力パワー（電子のジュール加熱とイオンの粘性加熱）と損失パワー（放射や伝熱等）がバラ ンスして, 平均の意味で熱エネルギー $\mathrm{p} /\left(\gamma_{\mathrm{s}}-1\right)$ は一定となる. 残る磁気エネルギーと流体的運動エネ ルギーの和

$$
W_{\mathrm{bv}}=\int\left[B^{2} /\left(2 \mu_{0}\right)+\rho v^{2} / 2\right] \mathrm{d} v
$$

の時間変化は

$$
\mathrm{d} W_{\mathrm{bv}} / \mathrm{d} t=-\int\left[\eta j^{2}+\nu_{\mathrm{d}} \Omega_{\mathrm{d}}^{2}+\operatorname{div}(\mathbf{E} \times \mathbf{B})\right] \mathrm{d} v
$$

と計算される。但し，誘導電場によるエネルギー入力は Poynting vector の項 $\operatorname{div}(\mathbf{E} \times \mathbf{B})$ で表現されてい る.誘導電場は先ず電子とカップルしてプラズマ電流を駆動し， $\eta j^{2}$ の項によって電子を加熱する。また， プラズマ電流による電磁応力によって不安定性が生じると, プラズマの運動が駆動され, $\nu_{\mathrm{d}} \Omega_{\mathrm{d}}^{2}$ の項によっ てイオンが加熱される.

誘導電場によって保持された準定常状態では

$$
\int_{\Omega}\left[\eta j^{2}+\nu_{\mathrm{d}} \Omega_{\mathrm{d}}^{2}\right] \mathrm{d} v=V_{\mathrm{L}} I_{\mathrm{P}}
$$

となる。I $I_{\mathrm{P}}$ はトロイダル電流である。

ヘリシティーバランスの式とエネルギーバラン

スの式とを比較し, 両者の違いを整理すると表 I の様になる。
表 |：エネルギーバランスとヘリシティー バランスの比較

\begin{tabular}{|l|c|c|}
\hline & エネルギーバランス & ヘリシティーバランス \\
\hline 全散逸量 & $\begin{array}{c}\int \eta j^{2} d v \\
+\int \nu_{d} \Omega_{d}{ }^{2} d v\end{array}$ & $\int \eta j \cdot B d v$ \\
\hline 入カ flux & Poynting Flux & Helicity Flux \\
\hline 全入カ & $v_{\mathrm{L}} \cdot I_{\mathrm{P}}$ & $v_{\mathrm{L}} \cdot \Phi_{\mathrm{t}}$ \\
\hline
\end{tabular}


研究論文

\section{4-2 電流密度分布の構造と異常散逸}

抵抗率 $\eta$ と電流密度 $\mathrm{j}$ の分布の関係について考えよう。2-3項で述べたように，平均場による異常散逸は， この両者の関係の “異常”によって起こる。このことを，4-1項で述べたへリシティー及びエネルギーの評価 式を用いて示そう。

先ず，“異常”とは何を意味するかを“正常”と対比して示す必要があろう．正常な場合， $\eta$ と $\mathrm{j}$ とは $\eta$

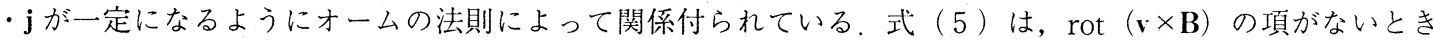
は，単純な拡散方程式で，この解は常に抵抗性電場 $\eta \mathbf{j}$ が一定となる定常解に収束する，定常解は，一定の電 流値 $I_{\mathrm{P}}=\int \mathbf{j} \cdot \mathbf{n d} s$ （面積分はプラズマの断面に互る）に対して, 全抵抗散逸 $P_{\mathrm{OH}}=\int \eta j^{2} \mathrm{~d} v$ を最小とす る分布である，実際， $I_{\mathrm{P}}$ を束縛として $P_{\mathrm{OH}}$ を最小化すると， $\eta \mathbf{j}=$ 一定というEuler 方程式が得られる。

電場 $\mathbf{E}_{\mathrm{ex}}$ が境界条件として与えられた場合には，導体中の抵抗性電場を均一にするような変分問題でオー ムの法則を表すことができる。即ち汎関数

$$
\mathrm{F}=\int[\operatorname{grad}(\eta \mathbf{j})]^{2} \mathrm{~d} v
$$

を，境界条件 $\eta \mathbf{j}=\mathbf{E}_{\mathrm{ex}}(=-$ 定，境界上）の下で最小化すれ ば上記の定常解（正常な電流分 布）が得られる。この境界条件 は,ヘリシティーバランスの式 （6）(勿論磁束 $\Phi_{\mathrm{t}}$ が 0 でない 時), 或はエネルギーバランス の式（７）（今の場合粘性散逸 $=$ 0 )を束縛条件とする Lagrange 型の条件と置き換えてもよい. つまり，古典的な（正常な）電 流分布の変分学的な特徽付に於 ELAREREA :
(no dynamo)

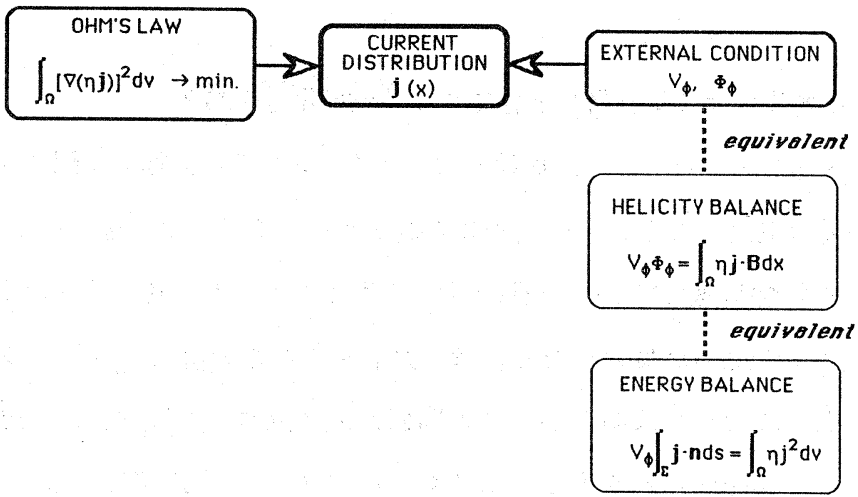

て, ヘリシティー入力, 或は工 ネルギー入力を条件として与え る事は, 駆動電場を境界条件と して与える事と等価である（図 3 参照）

ダイナモ項 $\operatorname{rot}(\mathbf{v} \times \mathbf{B})$ が

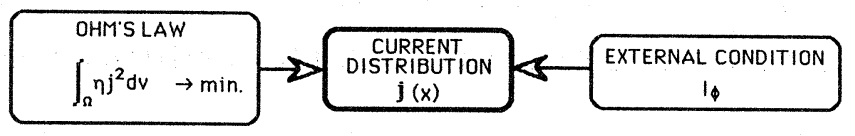

図 3.ダイナモ項 rot $(v \times B)$ を持たない系に於ける定常電流分布. 内的な法則はオームの法則, 外的条件は電場 (上図) 或は全電 流（下図）。 
支配的なプラズマ中ではこの様 な単純な関係は得られない。電 場 $\mathbf{E}_{\mathrm{ex}}$ で駆動される場合を考 えると，この境界条件とへリシ ティー入力の条件とは等価であ る（なぜなら，式（6）は抵抗 散冕項に部分積分を行った際の 境界項と内部項の関係に過ぎな い).しかし，エネルギー評価 の式 (7) はプラズマの運動を 反映する $\Omega_{\mathrm{d}}$ を含むから，明ら かに電場の境界条件では尽くせ ない内容を持つ。又, 内的な法

則も，電場が一定となるオームの法則ではなく，プラズマの力学的な法則と置き換えられる。即ち，jの分布 はプラズマが安定であり得る配位と站う部分集合の中で，ある種のエントロピー生産を最小とするような構造 を持つであろう。この様にして決められた $\mathbf{j} に$ 対してエネルギー評価（7）は a posterioriに成立する関係 と考える必要がある（図 4 参照），同じ電流值について比較すると，上記の電場＝一定の場合が抵抗散逸最小 であるから，当然それよりも大きな抵抗散逸が起こる筈である。

\section{4-3 平均場による抵抗散逸と摇動による粘性散逸の分配}

第 3 節で示したように，摇動の散逸はイオンの粘性散逸で支配されるから，式（7）の抵抗散逸はほとんど 平均場の電流によるジュール散逸であるとしてよい, 全散逸に対する, 平均場による抵抗散逸 $P_{\mathrm{OH}}$ と, 摇動 による粘性散逸 $P_{\mathrm{d}}^{\mathrm{i}}$ の分配について考えよう。4-2項で述べたように $P_{\mathrm{OH}}$ は $\eta$ との分布に強く依存す る. $P_{\mathrm{OH}}$ の比率が最大になるのは, $P_{\mathrm{OH}}=$ 全入力 $P_{\mathrm{IN}}, P_{\mathrm{d}}^{\mathrm{i}}=0$ となるときであり, 古典的な電流分布（ $\eta \mathbf{j}$ =一定）に対しては明らかにこの関係が成り立つ（ $P_{\mathrm{OH}} / P_{\mathrm{IN}}$ を最大とする変分問題を考えるとよい）。 もう一つ興味深い例がある。この場合には $P_{\mathrm{OH}}$ の“比率”が最大になるのみならず，与えられた電源電圧 $\left(\mathbf{E}_{\mathrm{ex}}\right)$ とトロイダル磁束に対して， $P_{\mathrm{OH}}$ の值自身も最大となる。変分を部算してみよう.

電場 $\mathbf{E}_{\mathrm{ex}}$ で駆動された系を考えるので，ヘリシティーバランスの関係を束縛として， $P_{\mathrm{OH}}=\int \eta j^{2} \mathrm{~d} v$ を 最大とする変分問題を考えればよい。境界条件に気を付けながら Euler 方程式を計算すると,

$$
\operatorname{rot}(\eta \operatorname{rot} \mathbf{B})=\mu[\eta \operatorname{rot} \mathbf{B}+\operatorname{grad} \eta \times \mathbf{B} / 2]
$$




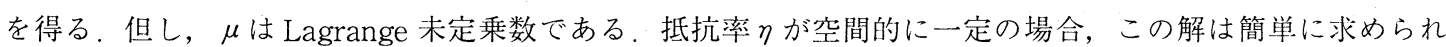
る。即ち,

$$
\operatorname{rot} \mathbf{B}=\mu \mathrm{B}
$$

Taylor state である。このとき， $P_{\mathrm{OH}}=P_{\mathrm{IN}}$ となる事は簡単に検証できる。 $\eta$ が一定の場合, Taylor state は，与えられたへリシティー入力（電源電圧とトロイダル磁束）に対して，最大のジュール加熱を実現する状 態，換言すれば最大のエネルギーを電源から吸収する状態であることが分かる.

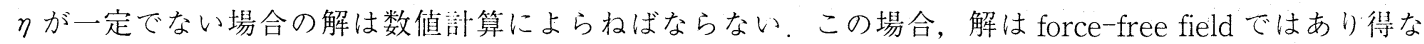
いことは簡単に分かる。実際， $\operatorname{rot} \mathbf{B}=\lambda \mathbf{B}(\lambda$ は一定である必要はない) と置き，式（８）に代入すると，

$$
\eta \lambda(\lambda-\mu) \mathbf{B}=\operatorname{grad}[\eta(\mu / 2-\lambda)] \times \mathbf{B}
$$

従ってクが一定 $(\operatorname{grad} \eta \times \mathbf{B}=0)$ でない限り解がない.

$\eta$ が一定でないプラズマに於て force-free 配位に近い状態が形成される場合には，相対的にP $P_{\mathrm{OH}}$ が小さ くなる. force-free fieldについては簡単に

$$
P_{\mathrm{OH}} / P_{\mathrm{IN}}=\left[\int B_{\mathrm{t}} \mathrm{d} s \int \eta \lambda^{2} B^{2} \mathrm{~d} v\right] /\left[\int \lambda B_{\mathrm{t}} \mathrm{d} s \int \eta \lambda B^{2} \mathrm{~d} x\right]
$$

となる事が分かる，但し， $B_{\mathrm{t}}$ は $\mathrm{B}$ のロイダル成分である、 $B^{2}$ は $B_{\mathrm{t}}$ よりも一般に平坦な関数である（磁 気圧〜一定)。もし $(\eta \lambda)$ もほぼ平坦な関数であると，ピーキングした入に対して， $P_{\mathrm{OH}} / P_{\mathrm{IN}}$ は 1 りも 小さくなり，従って $P_{\mathrm{d}}{ }^{\mathrm{i}}$ が相対的に大きくなる。Ortolani は $\eta$ とえ適当に選ぶと， $P_{\mathrm{d}}^{\mathrm{i}} / P_{\mathrm{IN}}$ が約 $50 \%$ 程度になり得ることを示している7）。この様な場合，非常に強いイオンの直接加熱が起こると考えられる。一

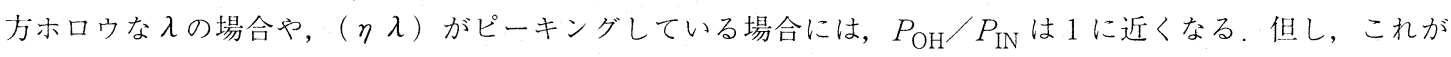
1 を越えるような平衡は保持できない.

\section{5.おわりに}

本稿では MHD 緩和現象とイオン直接加熱との関係について議論した。まとめると，摇動による散逸はイオ ンの粘性が支配しイオンの直接加熱に寄与すること，しかし平均場による異常な抵抗散冕が存在し，こ机は電 子チャンネルを通じてのエネルギー損失を意味することを述べた。笑際に前者と後者のエネルギー分配がどう なるのかは抵抗率 $\eta$ の分布に強く依存する。 force-free で近似するならば評価式（9）でよい。しかし，実

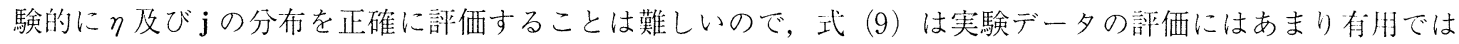




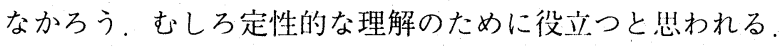

摇動による散逸について，第 3 節では粘性散逸と抵抗散逸との比を計算し，駆動磁気再結合のような成長率 が大きな不安定性の摇動については，圧縮性に伴う粘性散逸が支配的になることを示した。䛨算ではスラブモ デルを用いたが，本質的には評価（4'）のみであるから，もっと複雑な乱流状態を考えても本質的な違いは ないであろう。この摇動に伴う散逸の絶対值については，エネルギーバランスの関係から，平均場による異常 散逸の如何によって左右される，実験的にはプラズマ中の摇動の大きさは直接測定できないので，果してどの 位のエネルギーが摇動によって散逸されているのか明らかではない，理論的には平均場の保持に必要なダイナ モの強さが評価でき，それに伴う摇動の強度は，粘性散逸によってイオンの異常加熱を説明するに充分である と言う試算もあるが, まだ他の加熱機構もあるのかどうか, 今後の研究の余地がある.

\section{参考文献}

1) 吉田善章 : 核融合研究 62 (1989) 319 .

2) R. B. Howell and Y. Nagayama : Phys. Fluids 28 (1985) 743.

3) K. Ogawa, Y. Maejima, T. Shimada, Y. Hirano and Y. Yagi : Nucl. Fusion 25 (1985) 1295.

4) P. G. Carolan, et al. : in Proc. 14th Eur. Conf. on Controlled Fusion and Plasma Physics, Madrid, Vol.II (EPS, 1987) 469.

5) H. A.B. Bodin : in Proc. Workshop" Physics of Mirrors, Reversed Field Pinches and Compact Tori" , Vol. I (Varenna, 1987) 307.

6) Y. Kamada, et al. : Nucl. Fusion 29 (1989) 713.

7) S. Ortolani : Plasma Phys. Controlled Fusion 31 (1989) 1665.

8) C. G. Gimblett : Europhys. Lett. 11 (1990) 541.

9) A. Hasegawa : Adv. Phys. 34 (1985) 1.

10) R. Horiuchi and T. Sato : Phys. Rev. Lett. 55 (1985) 211.

11) J.B. Taylor: Phys. Rev. Lett. 33 (1974) 1139.

12) E. J. Caramana, R. A. Nebel and D.D. Schnack: Phys. Fluids 26 (1983) 1305.

13) T. Sato and T. Hayashi : Phys. Fluids 22 (1979) 1189.

14) T. Sato, R. Horiuchi and K. Kusano : Phys. Fluids B1 (1989) 255.

15）吉田善章: 核融合研究 60 (1988) 54 .

16) S.I. Braginskii : in Reviews of Plasma Physics, Vol.1 (Consultants Bureau, New York, 1965) 205. 